\title{
Metabolic syndrome and blood pressure: are they related or not?
}

This article was published in the following Dove Press journal: Diabetes, Metabolic Syndrome and Obesity:Targets and Therapy

\author{
Venu Gopal Jonnalagadda' \\ Shravan Kumar Uppulapu² \\ 'Department of Pharmacology \\ and Toxicology, National Institute \\ of Pharmaceutical Education and \\ Research, Mirza, Assam, India; \\ ${ }^{2}$ Department of Biotechnology, \\ National Institute of Pharmaceutical \\ Education and Research, Mirza, Assam, \\ India
}

Correspondence: Venu Gopal Jonnalagadda

Department of Pharmacology and Toxicology, National Institute of Pharmaceutical Education and Research, C/O NETES Institute of Technology \& Science, NH-37, Shantipur, Parli Part, Mirza, Assam 78I I25, India

Tel +9l 9892588207

Fax +9| 36I 2529457

Email gopalvenu63@gmail.com

\section{Dear editor}

We have read the article "Testosterone, obesity, and waist circumference as determinants of metabolic syndrome in Saudi women" by Fatani et al with great interest. ${ }^{1}$

As per National Cholesterol Education Program Adult Treatment Panel III guidelines, metabolic syndrome (MS) is diagnosed on the basis of the presence of three or more of the following five criteria: waist circumference (WC) over 40 inches (men) or 35 inches (women), fasting triglyceride (TG) level over $150 \mathrm{mg}$ / $\mathrm{dL}$, blood pressure (BP) over 130/85 mmHg, fasting blood sugar over $100 \mathrm{mg} / \mathrm{dL}$, and fasting high-density lipoprotein (HDL) cholesterol level $<40 \mathrm{mg} / \mathrm{dL}$ (men) or $50 \mathrm{mg} / \mathrm{dL}$ (women). ${ }^{2}$

Moreover, as per new JNC-8 guidelines, hypertension is defined as BP $\geq 140 / 90 \mathrm{mmHg}$, and in general, SBP value is more than DBP. ${ }^{3}$ However, in the aforementioned article, SBP was presented as $70.19 \pm 3.66$ in the control group and $106.62 \pm 5.67$ in the MS group, and DBP was presented as $113.27 \pm 1.17$ in the control group and $134.58 \pm 2.08 \mathrm{mmHg}$ in the MS group. Specifically, increased DBP is secondary to another disorder of kidney or sleep apnea syndrome and thyroid. ${ }^{4}$

We would be highly obliged for your kind consideration of the abovementioned clarification in your article to avoid discrepancy and highlight a clear idea of the relationship between testosterone, obesity, and WC in the prediction of MS.

\section{Disclosure}

The authors report no conflicts of interest in this communication.

\section{References}

1. Fatanni SH, Abdelbasit NA, Al-Amodi HS, Mukhtar MM, Babakr AT. Testosterone, obesity, and waist circumference as determinants of metabolic syndrome in Saudi women. Diabetes Metab Syndr Obes. 2018;11:175-181.

2. Huang PL. A comprehensive definition for metabolic syndrome. Dis Model Mech. 2009;2(5-6):231-237.

3. Bell K, Twigg J, Olin BR. Hypertension: The Silent Killer: Updated JNC-8 Guideline Recommendations. Available from: http://c.ymcdn.com/sites/www.aparx.org/resource/resmgr/CEs/CE_Hypertension_The_Silent_K.pdf. Accessed May 9, 2018.

4. Livestrong.com. Causes of High Diastolic Blood Pressure. Available from: https://www.livestrong.com/ article/136545-causes-high-diastolic-pressure/. Accessed May 9, 2018. 
Dove Medical Press encourages responsible, free and frank academic debate. The content of the Diabetes, Metabolic Syndrome and Obesity: Targets and Therapy 'letters to the editor' section does not necessarily represent the views of Dove Medical Press, its officers, agents, employees, related entities or the Diabetes, Metabolic Syndrome and Obesity: Targets and Therapy editors. While all reasonable steps have been taken to confirm the content of each letter, Dove Medical Press accepts no liability in respect of the content of any letter, nor is it responsible for the content and accuracy of any letter to the editor.

Diabetes, Metabolic Syndrome and Obesity: Targets and Therapy

Publish your work in this journal

Diabetes, Metabolic Syndrome and Obesity: Targets and Therapy is an international, peer-reviewed open-access journal committed to the rapid publication of the latest laboratory and clinical findings in the fields of diabetes, metabolic syndrome and obesity research. Original research, review, case reports, hypothesis formation, expert opinion and commentaries are all considered for publication. The manuscript management system is completely online and includes a very quick and fair peer-review system, which is all easy to use. Visit http://www.dovepress.com/testimonials.php to read real quotes from published authors.

Submit your manuscript here: https://www.dovepress.com/diabetes-metabolic-syndrome-and-obesity-targets-and-therapy-journal 